\title{
Anthropology in Papua New Guinea: History and Continuities
}

\author{
Martin Soukup \\ Katedra teorie kultury (kulturologie) Filozofické fakulty Univerzity Karlovy v Praze, Celetná 20, 11000 Praha 1
}

\section{ANTROPOLOGIE NA PAPUI-NOVÉ GUINEJI: HISTORIE A SOUVISLOSTI}

ABSTRAKT Předmětem studie je analýza dějin antropologie v Melanésii se zvláštním přihlédnutím k oblasti dnešního nezávislého státu Papua-Nová Guinea. Autor věnuje pozornost vývoji antropologických výzkumů na Papui v období od poslední třetiny 19. století do šedesátých let 20. století. Rozlišuje tři hlavní fáze antropologických výzkumů v této kulturní oblasti: fáze prvního kontaktu v 19. století, přípravná fáze od přelomu století do poloviny dvacátých let a zlatý věk od poloviny dvacátých let do šedesátých let 20. století. Autor hájí tezi, že výzkumy uskutečněné na Papui zásadním způsobem přispěly k rozvoji teorie a metodologie antropologie a formovaly její dnešní povahu.

KLÍČOVÁ SLOVA antropologie; dějiny; Melanésie; Papua-Nová Guinea

\begin{abstract}
The aim of this paper is to explore the history of anthropology in Melanesia with a particular attention to the territory of the current independent state of Papua New Guinea. Author analyzes the history of the anthropological research in Papua from the late $19^{\text {th }}$ century until the sixties. The author distinguishes three phases of history of anthropology in Papua: a phase of the first anthropological contact in the late $19^{\text {th }}$ century, a phase of the nidation until the middle of twentieth century and a phase of the gold age of the anthropology in Papua, from the middle to the sixties of the twentieth century. Author argues that the fieldworks conducted in Papua changed the face of anthropology in a profound way. In the last part of the paper author summarizes main achievements and progress in anthropology of Melanesia in the framework of anthropology as such.
\end{abstract}

KEY WORDS anthropology; history; Melanesia; Papua New Guinea

\section{INTRODUCTION}

Anthropology as a scientific discipline have shaped in the $19^{\text {th }}$ century, when scholars studied natives and their cultures mainly in the libraries. So called "armchair anthropologists" did their job and never met face to face the subject of their interest - so called "primitives". Exemplary is an answer of a British anthropologist James George Frazer (1854-1941) to a question what kind of natives he witnessed: "But God, forbid" (quoted Herdt 1982, X). In spite of theoretical nature of his work Frazer played important role in Melanesian anthropology. Although he did not perform any fieldwork, he was a highly recognized anthropologist, who inspired young anthropological generations. Bronisław Malinowski has de- cided to be an anthropologist after he had read Frazer's opus magnum The Golden Bough (Frazer 1890), which Malinowski designated as "(...) perhaps the greatest scientific Odyssey in modern humanism" (Malinowski 2002, 211) and Malinowski also declared that Frazer is "the greatest anthropologist of our age" (quoted Kardiner - Preable 2002, 92). Malinowski is a key figure of modern anthropology, and started an anthropological tradition of a long-term research by his memorable fieldwork among Trobriand islanders. Although Malinowski's work is a masterpiece of anthropology, he had predecessors and followers in Melanesia, who partook in both developing anthropology of Melanesia and expansion and progress of anthropology as such. In this context we could designate Melanesia as main "laboratory" of a modern cultural and social anthropology. 


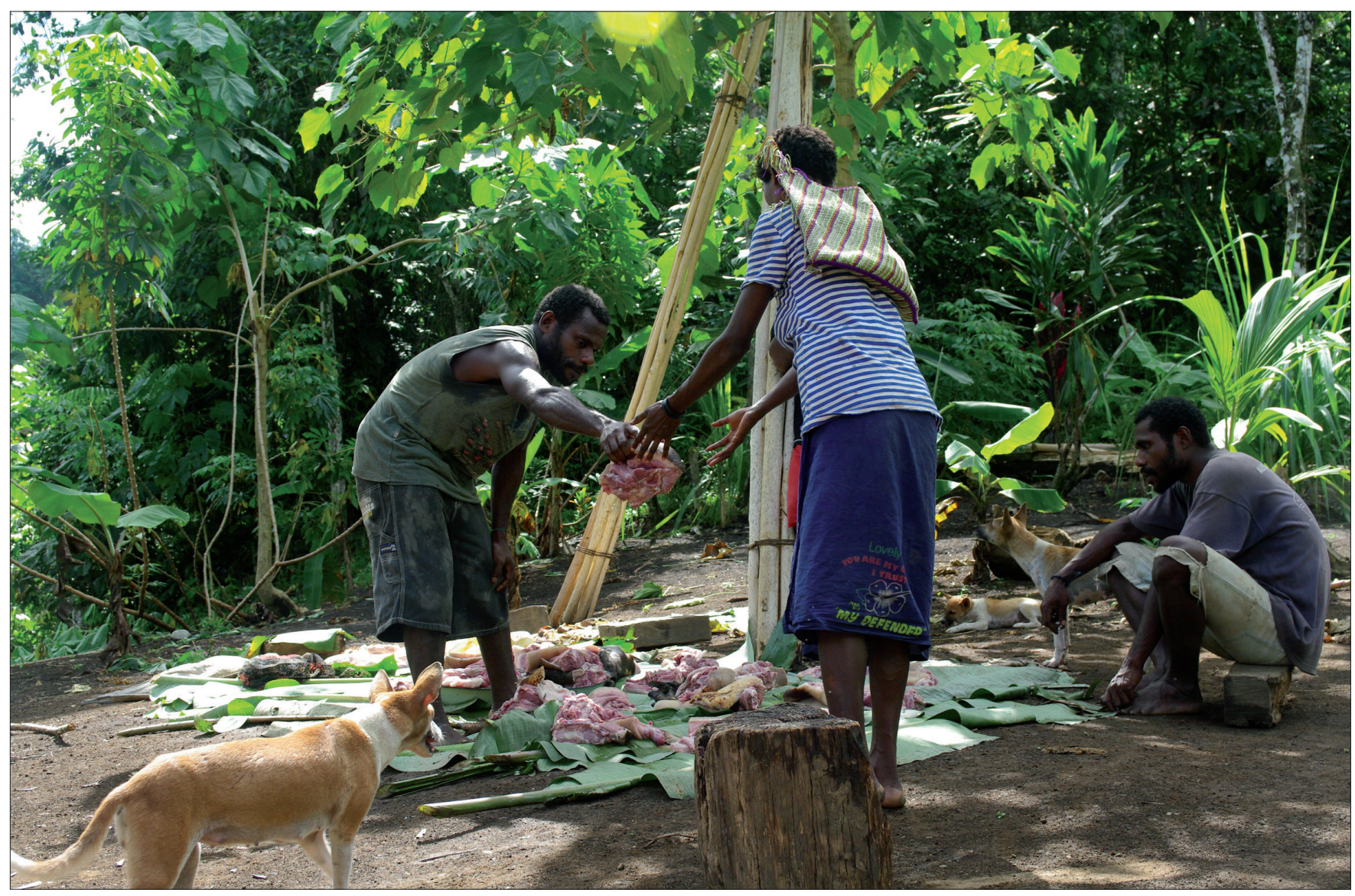

Fig. 1. European anthropologists firstly studied lowland Papuan cultures in the area of Madang. The leader of the clan goes share killed pig with the families. Wannang village, Madang Province, 2009. Photo: Martin Soukup.

\section{FIRST ANTHROPOLOGICAL CONTACT}

The discovery of a cultural area of Melanesia has begun in the $16^{\text {th }}$ century especially by the Spanish and Portuguese seamen. Spaniard sailor Alvaro de Saavedra (?-1529) in 1529 (Moore 2003; Collingridge 2007) was probably the first European sailor to lay his eyes on the shores of New Guinea. The first contact situations in different parts of Melanesia had very similar patterns. Papuans often interpreted Europeans as returning spirits of the dead ancestors who dispose of a magical power, which they could use for or against the natives. Europeans interpreted the first contact as "friendly" or "hostile". Whittaker argues that nature of the first contacts depended on perception and interpretation from the natives point of view. If natives had suppose that "spirit of the dead" intended to use its power for the natives then relationships were amicable; if it was to the contrary relationships tend to be hostile (Whittaker 1971). The contacts between European and Papuans were rather casual until the end of $19^{\text {th }}$ century. One of the reasons is that the trading companies preferred a quick profit, which New Guinea from a geographical as well as climatic viewpoint did not offer at the first sight. That is why European traders, travelers and scientists were initially disinterested to gain a detailed knowledge of Papua. It is possible to say that Papua was merely a source of a cheap labour for plantations. But the situation was going to change at the end of the $19^{\text {th }}$ century. As late as circa 1870 Papua turned to be a region with an economic potential. Not until this time Europeans aspired to pervade the inland of New Guinea (Whittaker 1871). Therefore scientists came to be systematically interested in the Papuan culture and nature relatively late. We could distinguish three more or less independent phases of Melanesian anthropology. The first phase is the very end of the $19^{\text {th }}$ century when European scientist made the first contacts with Papuans. A key researcher of this period was a Russian ethnographer and scientist Nicholas MiklouhoMaclay (1846-1888) who spent a long time among natives in current Madang district (Fig. 1). Maclay as a very first European scientist undertook a long-term research within New Guinean communities even before the establishment of German colony in New Guinea in 1884. His diaries and published papers are an unique source of information on cultures in Madang district in the period of the first contact between natives and Europeans (see Miklukho-Maklai 1982). The second important researcher of this period was a German ornithologist Otto Finsch (1839-1917) who explored the same area as Maclay in order to help to establish a German colony in New Guinea. Finsch published Ethnologische Erfah- 
rungen und Belegstücke aus der Südsee: Beschreibender Katalog einer Sammlung in k. $k$. naturhistorischen Hofmuseum in Wien (3 vol.) and Samoafahrten. Reisen in Kaiser Wilhelms-Land und Englisch-Neu-Guinea in den Jahren 1884 u. 1885 an Bord des Deutschen Dampfers „Samoa“ (Finsch 1888, 1888-1893, 1996). These accounts are among the gold ethnographical resources. However his importance for the advancement of anthropology of Melanesia unfortunately remain marginal, mainly because his works remained untranslated into English. This period of anthropological research in Papua was not systematical. Much of all research was performed by missionaries rather then scientists and anthropologists. A key missionary of that time was Robert Henry Codrington (1830-1922), who introduced into anthropology the term mana, which was an important concept in the anthropology of religion in the first half of $20^{\text {th }}$ century (Codrington 1891; see van Baal 1971). Most considerable missionaries who worked in Papua were also James Chalmers (1841-1901), John Gibson Paton (1824-1907) a John Coleridge Patteson (1827-1871) (Mückler 2009). We can say that the anthropologists at the turn of the century followed the missionary footprints. Crucial age of anthropology in Papua began at the turn of the century.

\section{FROM TORRES EXPEDITION TO THE LONG-TERM FIELDWORKS IN PAPUA}

The next phase of the development of anthropology in Papua began at the turn of the century and is linked to the shaping of anthropology as a field science. Decisive moment in anthropological transition from armchair studies to fieldwork research was a memorable Cambridge expedition to the Torres Strait in 1898 under the guidance of British scientist and anthropologist Alfred Cort Haddon (1855-1940). He organized interdisciplinary team of scientists, linguists, anthropologists, psychologists, photographers who participated in exploration of communities in Torres Strait. On this famous expedition participated key figures of British social anthropology of the first third of the $20^{\text {th }}$ century - except of Haddon also William Halse Rivers Rivers (1864-1922) and Charles Gabriel Seligman (1873-1940). Expeditions plowed Torres Strait from the April till the October. The most intensive survey team carried out research within five weeks in September and October, namely on the islands Mer and Mabuiag (Kuper 2005). Subsequently Haddon has been publishing between 1901-1935 six volumes reports on Torres Strait expedition but the theoretical impact of these was rather marginal. From the viewpoint of anthropological methodology and theory the genealogical method were important and Rivers developed and verified it in the course of the expedition. Moreover, the team applied psychological methods and took short movies. Importance of this expedition consists in the fact that anthropologists stepped out of the libraries and started work in situ; expedition is then rightly marked as turning point of anthropology (Barth 2005). Although some anthropologists have continued to work in armchair, anthropological mainstream shaped anthropology as a field science. Torres Expedition was important as a formative moment of British social anthropology. First two-thirds of the 20th century is possible to call "the golden age" of anthropology in Papua. During this time key figures of anthropology undertook fieldwork in Melanesia. First twenty five years of the century could be marked as a period of the "nidation". During this time anthropologists undertook a first long-term research in Papuan communities and crucial institutions of colonial administrations were established. In the course of this preparatory period, which continued to the middle of twenties, crucial figures of the anthropology undertook the anthropological fieldworks in Papua: Wallace Edwin Armstrong (1896-1980), Diamond Jenness (1886-1969), Gunnar Landtman (1878-1940), Bronisław Kasper Malinowski (1884-1942), Richard Parkinson (1844-1909), Charles Gabriel Seligman (1873-1940), Richard Thurnwald (1869-1954), John Whiting (1908-1999), Francis Edgar Williams (1893-1943), Robert Wood Williamson (1856-1932), Paul Wirz (1892-1955). Since the middle of twenties fieldwork researches were conducted in Papua and we today regard them as a classical example of anthropological work. Gregory Bateson (1904-1980), Reo Franklin Fortune (1903-1979), Ian Hogbin (1904-1989), Margaret Mead (1901-1978), Hortense Powdermaker (1900-1970), Géza Róheim (1891-1953) are the most considerable. Anthropologists of this period conducted fieldwork in the communities on the relatively small islands across Papua as well as among coastal people of the New Guinea mainland. This generation of fieldworkers focused on the research of sociocultural process as enculturation and socialization, initiation rituals or economical and religious life (Herdt 1982). The mainstream cultural anthropology was governed especially by Malinowski, Mead and Seligman at that time. The impact of the works published by other noted anthropologists was rather marginal in this period or came later like in the case of Bateson, Hogbin or Powdermaker.

Extraordinary person of this period of Melanesian anthropology was a Finnish anthropologist and philosopher Gunnar Landtman who was a pupil of a famous Finnish anthropologist Edvard Westermarck (1862-1939). Landtman conducted a fieldwork on the Kiwai Island in the delta New Guinea's longest river Fly. Landtman visited Haddon at Cambridge and discussed the possibility of travel in order to study the nonEuropean culture. Haddon later wrote in the introduction to Landtman's book that Landtman at that time declared: "I will go anywhere in the world you like to send me" (Landtman 1927, $\mathrm{X})$. Haddon with his colleagues conducted above mentioned fieldwork in Torres Strait but he was also aware of unsatisfactory knowledge of the cultures in Torres Strait. That is why he decided to send Landtman to Torres Strait where he should have study way of life on Kiwai Island (Lawrence 2010). As a first European anthropologist Landtman conducted intensive fieldwork among Kiwai. He was in the Melanesia nearly five years before Malinowski and used the method of participant observation. Subsequently he published various articles 


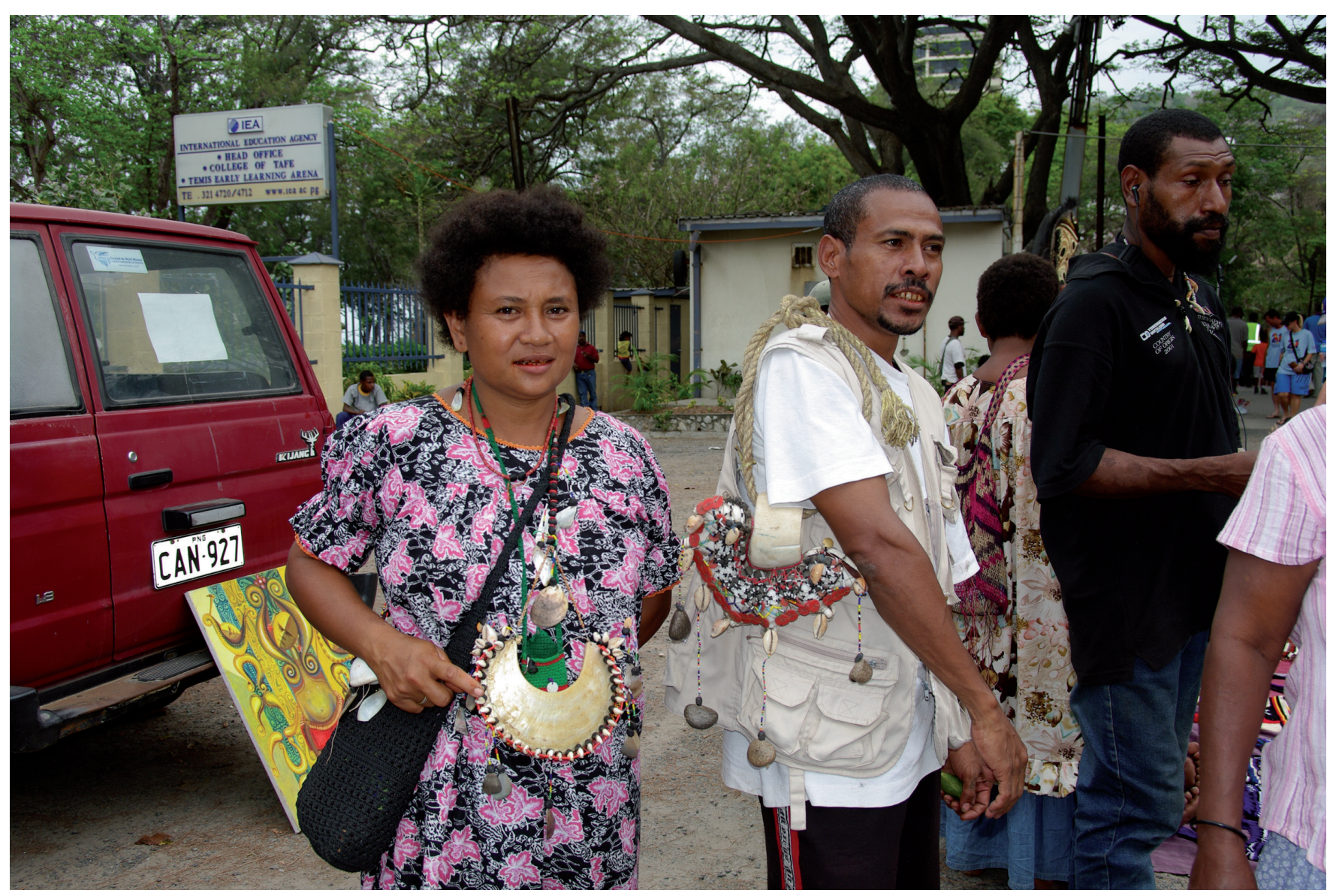

Fig. 2. Trobrianders sell the famous kula artefacts - soulava and mwali, which Bronisław Malinowski described in his classic Argonauts. Marketplace in Port Moresby, 2009. Photo: Martin Soukup.

on the topic of Kiwai people and their culture. His monograph appeared in 1927, five years later then Malinowski's classic Argonauts - a book that made Malinowski an iconic anthropological figure, and in which he interpreted the ceremonial exchange kula (Malinowski 1922) (Fig. 2). Historian of anthropology George Stocking argues that delay of English edition of Landtman's monograph on Kiwai is the main reason why Malinowski overshadowed Landtman (Stocking 1992). We could sum up that the anthropological community gave priority to Kiriwina over Kiwai.

Sir John Hubert Plunkett Murray (1861-1940), LieutenantGovernor of Papua, had an important role in the development of anthropological research in Melanesia. He served as Lieutenant-Governor since 1908 until his dead in 1940. During this long time he had influenced progress of anthropology in Papua. Murray had read anthropological classics of the $19^{\text {th }}$ century (especially books by Tylor and Maine) and kept contacts with Haddon, Seligman and Marett. In 1912 he appointed experienced Armstrong as an Assistant Government Anthropologist. Armstrong had been conducting short-term research in local Papuan communities and preparing reports with additional recommendations. But Murray wasn't satisfied - he wanted to perform an analysis of the data himself and consequently to make the decisions (Gray 1999; Urry
1985). His original support of anthropology and anthropologists has been gradually changing to hostility towards anthropologists in the Melanesia. He had rather tensed relationship with Malinowski and Fortune (Gray 1999).

A crucial role in the development of anthropology in Papua was played by an Australian anthropologist Ernst William Pearson Chinnery (1887-1972) who joined the Papuan colonial administration in 1909. In 1917 Chinnery entered the forces; after the demobilization he studied anthropology in Britain under the guidance of Haddon and Rivers at Cambridge. He received a just diploma in anthropology. After his return to Australia, he was appointed as a Government Anthropologist in 1924 and from 1932 served as a Director of District Services. Later he also worked as a Commonwealth Advisor for Native Affairs and as a Director of the Native Affairs Branch in the Northern Territory administration (Gray 2008). Chinnery actively supported founding department of anthropology at the University of Sydney where many colonial officials studied anthropological theory and methodology. During interwar period Chinnery operated as a crucial colonial power in Papua and tried to balance the trilateral configuration of interests - often incompatible interests of anthropologists, colonial officials and natives. Chinnery believed in anthropology as a suitable tool for good administra- 


\begin{tabular}{|c|c|c|c|c|}
\hline & Anthropologist & Fieldwork & Period & Monograph \\
\hline \multirow{9}{*}{ 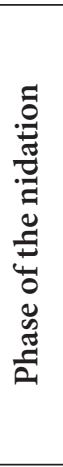 } & Seligman & Koit and Motu & 1904 & 1910 \\
\hline & Williamson & Mafulu & 1910 & 1912 \\
\hline & Landtman & Kiwai island & $1910-1911$ & 1927 \\
\hline & Jenness & Bwaidogu (Milne Bay) & 1911-1912 & 1920,1928 \\
\hline & Thurnwald & Bánaro & $1913-1915$ & 1916,1921 \\
\hline & Malinowski & Mailu & $1914-1915$ & 1915 \\
\hline & & $\begin{array}{l}\text { Trobriand islanders } \\
\text { (Kiriwina village) }\end{array}$ & $1915-1918$ & $\begin{array}{l}1922,1926,1927, \\
1929,1935\end{array}$ \\
\hline & Armstrong & Rossel Island & 1921 & 1928 \\
\hline & Williams & Oroko & $1923-1925$ & $\begin{array}{l}1928,1930,1936, \\
1940\end{array}$ \\
\hline \multirow{14}{*}{ 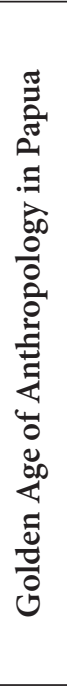 } & \multirow{4}{*}{ Fortune } & Dobu & $1927-1928$ & 1932 \\
\hline & & Manus & $1928-1929$ & 1935 \\
\hline & & Arapesh, Mundugumor, Chambuli & $1931-1933$ & 1942 \\
\hline & & Purari (Kamano) & 1935 & $\begin{array}{l}\text { Circa } 1936 \\
\text { (unpublished) }\end{array}$ \\
\hline & \multirow{3}{*}{ Mead } & Manus & $1928-1929,1953$ & 1930,1956 \\
\hline & & Arapesh, Mundugumor, Chambuli & $1931-1933$ & 1935 \\
\hline & & Iatmul & $1938-1939$ & partly 1946 \\
\hline & Wirz & Gogodala (Gogodara) & $1929-1930$ & 1934 \\
\hline & Bateson & Iatmul & $1929-1933,1938-1939$ & 1936 [1958] \\
\hline & Powdermaker & Lesu & $1929-1930$ & 1930 \\
\hline & Roheim & Normanby Island & 1930 & - \\
\hline & \multirow{2}{*}{ Hogbin } & Wogeo & 1934 & 1970 \\
\hline & & Busama & $1944-1945$ & 1951 \\
\hline & Whiting & Kwoma & $1935-1936$ & 1941 \\
\hline
\end{tabular}

Table 1. SEQ table Key anthropological research in Papua in the second phase of the development of anthropology in Papuai.

tion. As wrote in Gray: "(...) he was well versed in all matters to do with an anthropology premised on assisting colonial administrations to help advance and uplift indigenous populations" (Gray 2010: 239-238). Many anthropologists of this time appreciated Chinnery's hospitality and helpfulness in their books (see for example Bateson 1958, Fortune 1969, Mead 1935, Hogbin 1996). That is why Stocking designated Chinnery as "gatekeeper to the field" (Stocking 1982).

\section{INTO THE UNKNOWN - HIGHLANDS OF PAPUA}

In the golden age of antropology in Papua a new impulse to the anthropological research was given when in the thirties an Australian traveler, prospector and adventurer Michael Leahy (1901-1979) with his crew penetrated by that time practically unknown highlands as well as the plateau in the highlands of New Guinea. Michael Leahy repeatedly traveled since 1930 well until 1935 into central highlands and successively discovered highly populated area of this island about which nobody had any notion before (Fig. 3, 4). The first contact with the highlanders was very impressive; natives typically interpreted incomers as spirits of the dead ancestors
(Leahy 1991; Connolly - Anderson 1988). Leahy described unexpected discovery that highlands are densely inhabited, by these words: "This land was populated by tens of thousands of Stone Age natives, whose village fires at night extended in the distance as far as the eye could see across the grass valleys and ranges" (Leahy 1991, 10). Leahy understood that this is very unique first contact situation. That is why he recorded and gathered information, but his ethnographical effort was not a very systematic one. Due to Leahy's effort we now dispose of unique movies, a book and few papers, which are considered the best heritage of Leahy's travels (Leahy - Crain 1937, Leahy 1991, Connolly - Anderson 1988). Leahy opened up the path to the highlands of New Guinea only for short period, because at the beginning of 1935 colonial officials forbid to penetrate the highlands areas by European incomers. This protection was maintained until the Japanese invasion in December 1941. During the forties the highlands weren't under the control of local authorities and anthropological research due to both unstable situation and Japanese occupation did not take its course. At the end of this decade patrols had partly stabilized highlands area so the anthropologists could start their job in this still rather unknown cultural territory (Hays 1992). Anthropologists in the fifties and sixties went to carry 


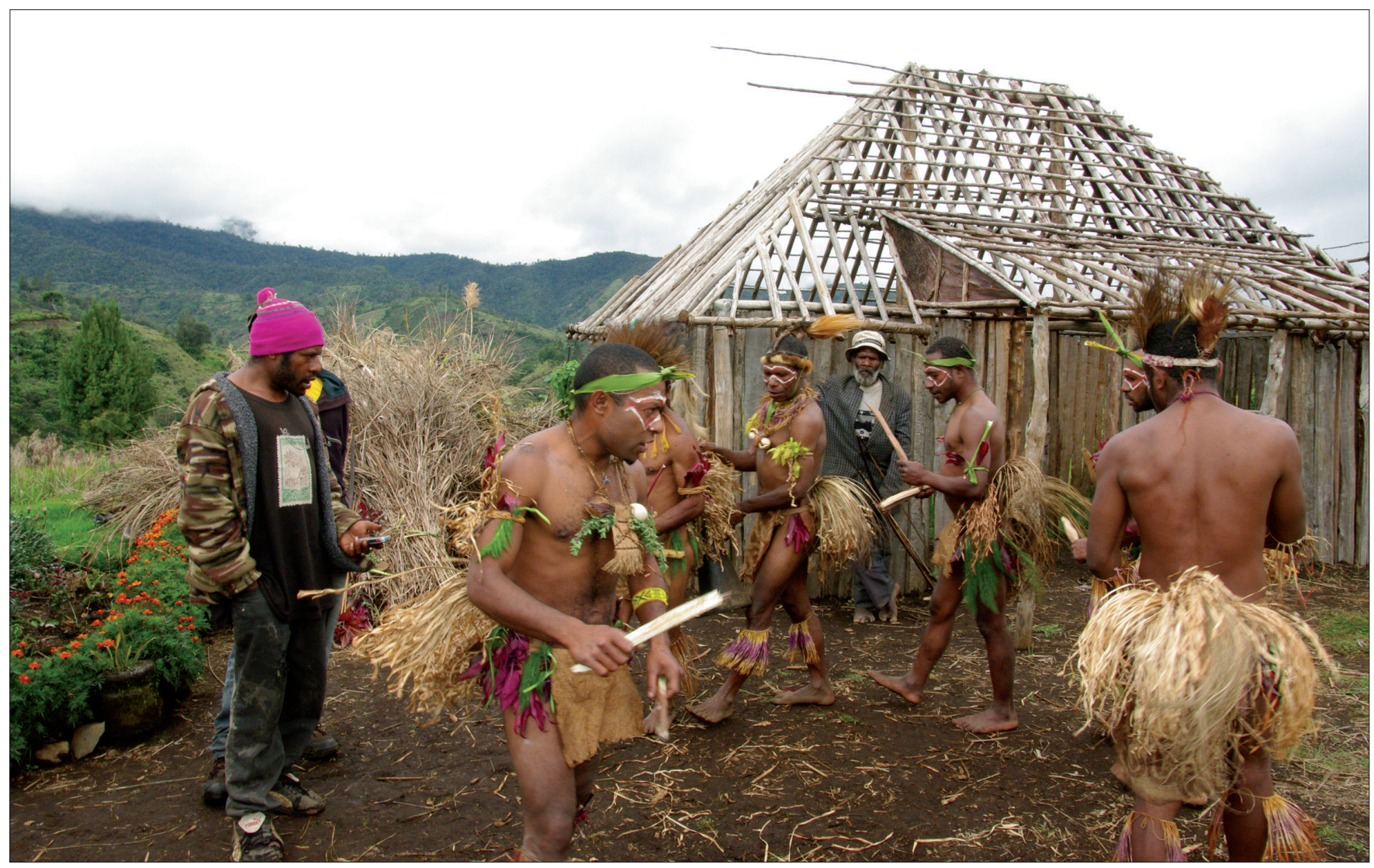

Fig. 3. Papuan way of life is influenced by the globalizing processes. Traditional culture is show for tourists. Kegesuglo village, Mt. Wilhelm, Chimbu province, 2009. Photo: Martin Soukup.

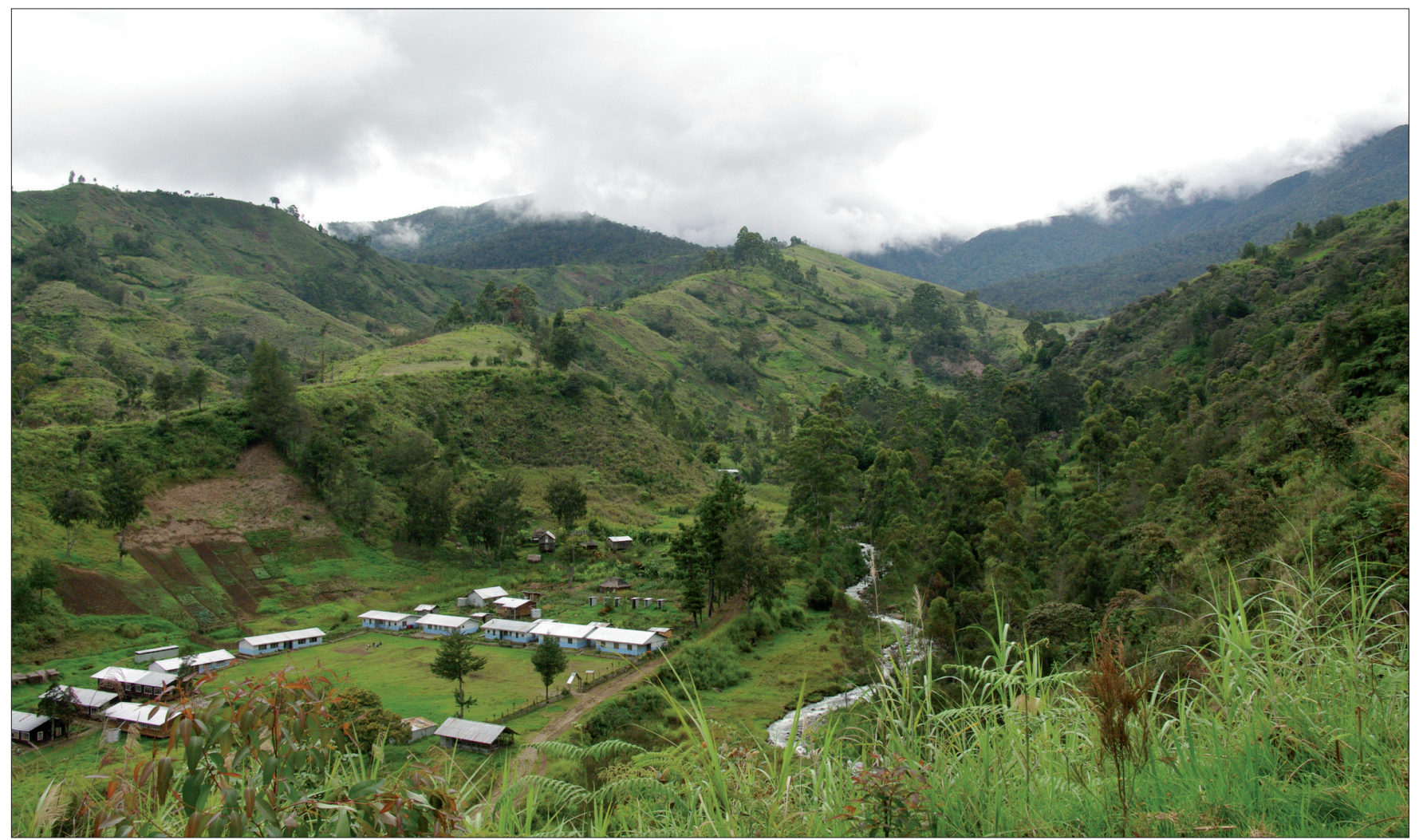

Fig. 4. Highly populated highlands were unknown till 1930s. Kegesuglo village, Mt. Wilhelm, Chimbu province, 2009. Photo: Martin Soukup. 


\begin{tabular}{|c|c|c|c|}
\hline Anthropologist & Fieldwork & Period & Monograph \\
\hline Read & Gahuku-Gama & $1944-1945,1950-1952$ & 1965,1986 \\
\hline Wirz & Kundiawa and Mount Hagen & 1950 & - \\
\hline Salisbury & Siane & $1951-1952$ & 1962 \\
\hline Berndt \& Berndt & Kainantu & $1951-1953$ & 1962 (by R. Berndt) \\
\hline J. B. Watson & $\begin{array}{l}\text { Tairora (Haparira) } \\
\text { Aiamontina (Agarabi) }\end{array}$ & $1953-1955$ & 1983 \\
\hline \multirow{2}{*}{ V. D. Watson } & Tairora and Agarabi & $1953-1955$ & 1965 (Ph.D. dissertation) \\
\hline & Tairora and Gadsup & $1963-1964$ & - \\
\hline Reay & Kuma & $1953-1955$ & 1959 \\
\hline Meggitt & Mae Enga & $1955-1957,1961-1962$ & 1965,1977 \\
\hline Bulmer & Kayka people & $1955-1956,1959-1960$ & 1960 (Ph.D. dissertation) \\
\hline Brown & Chimbu (mainly Mintima village) & $1958-1960$ & 1972 \\
\hline Epstein & Tolai People (New Britain, Rabaul) & 1959-1960, 1968, 1986, 1994 & 1969,1992 \\
\hline Rappaport & Tsembaga Maring & $1962-1963$ & 1968 \\
\hline \multirow{2}{*}{ A. Strathern } & Melpa & $1964-1965,1973-1974$ & 1971,2000 \\
\hline & Wiru & 1967 & - \\
\hline M. Strathern & Melpa & $\begin{array}{l}1964-1965, \quad 1967, \quad 1970-1971, \\
1976,1981,1995\end{array}$ & 1972,1988 \\
\hline Barth & Baktaman & $1968,1972,1981-1982$ & 1975,1987 \\
\hline
\end{tabular}

Table 2. SEQ table Anthropological fieldworks in the Papua highlands.

out a fieldwork in the highlands in the footprints of Leahy's company. The fieldwork was mostly conducted by a married couple Catherine Helen Berndt (1918-1994) and Ronald Murray Berndt (1916-1990), Paula Brown (born 1925), Ralph Neville Hermon Bulmer (1928-1988), Arnold Leonard Epstein (1924-1999), Mervyn J. Meggitt (1924-2004), Richard Roy Rappaport (1926-1997), Kenneth Read (1917-1995), Marie Reay (1922-2004), Frank Salisbury (1926-1989), Dame Ann Marilyn Strathern (born 1941), Andrew Strathern (born 1939), Virginia Drew Watson (1918-2007), James Bennett Watson (1918-2009). A strong wave of anthropological fieldworks then began in the highlands in the fifties and continued until the sixties. Anthropologists in their researches of the highlands focused on the social structure, kinship system, sociopolitical exchange, ecological and technological infrastructure et cetera. They almost omitted religion, rituals and symbolic systems (Herdt 1982: xvii). Typical research of that time were as follow: a research in ecology of Tsembaga Maring done by Rappaport (1984), a research of sociopolitical exchange moka in Mount Hagen communities carried out by Andrew Strathern (1971) or Berndt's monograph on a social control and a social order among highland communities Fore, Kamano, Usufura and Jate (Berndt 1962). This shift of topics of anthropological researches in Papua answers to the general change of anthropological thought in the middle of the cen- tury. During the fifties and sixties mainly structuralism, ethnoscience, structural-functionalism and ecologic approach was in the spotlight of anthropology. Ethnoscience and structuralism in the sense of Lévi-Strauss were not practically applied by anthropologists at that time in Papua. Anthropology in Papua took place dominantly in the framework of structural-functionalism and in the ecological approach. Typical example is above mentioned Berndt's work (1962), who linked his analysis of excess and restraint to the masters of functionalism Émile Durkheim (1858-1917) and Alfred Reginald Radcliffe-Brown (1881-1955). Excellent example of the ecological anthropology in Papua is Rappaport's monograph Pigs for the Ancestors (Rappaport 1984). The Papuan cultures appeared to be the ideal choice for these diverse anthropological interests. As written by Paula Brown, "environment and resources, population movements and growth, agriculture, technology, trade, the introduction of new goods and ideas, production, allocation of property, group structure, social activities, cooperation, alliances, competition, and patterns of dominance combine to make the distinctive highlands society and culture" (Brown 1979, 234-235). In addition highlands communities have remained relatively intact in the fifties; it would seem to be the anthropological "Holy Grail".

A new shift in the anthropology in Papua has been in progress since the mid sixties and mainly seventies. This shift is a con- 


\begin{tabular}{|l|l|l|}
\hline Domain of anthropology & Anthropologist & Fieldwork in locality or community \\
\hline \multirow{2}{*}{ Economic anthropology } & Malinowski & Trobriand islands \\
\cline { 2 - 3 } & Strathern & Melpa \\
\hline Anthropology of kinship & Rivers & Torres Expedition \\
\hline Psychological anthropology & Thurnwald & Bánaro \\
\hline & Mead & Manus, Arapesh, Mundugumor, Chambuli \\
\hline & Powdermaker & Lesu \\
\hline & Roheim & Dobu \\
\hline Anthropology of religion & Fortune & Dobu, Manus \\
\hline & Barth & Baktaman \\
\hline & Hogbin & Wogeo \\
\hline & Lawrence & Madang district \\
\hline Ecological anthropology & Rappaport & Tsembaga Maring \\
\hline Political Anthropology & Berndt & Fore, Kamano, Usufura, Jate \\
\hline Anthropology of Body & Hogbin & Wogeo \\
\hline
\end{tabular}

Table 3. SEQ table The Progresses of the domains of anthropology concerning anthropological fieldworks in Melanesia.

sequence of re-orientation on the symbolic systems - religion, cosmologies, initiation rituals et cetera. This new trend in anthropology in Papua is not the subject of this paper though. But in general, it's possible to summarize that this trend corresponds with the rise of symbolic, interpretative and cognitive approach in anthropology in general. Following researches or works are the gems of anthropology of Papua: Frederik Barth (born 1928) among Baktaman (Barth 1975, 1987), Gilbert Herdt (born 1949) among Sambia, which is pseudonym created by him (Herdt 1981), Donald Tuzin (1945-2007) among Arapesh (Tuzin 1976, 1980) or study on cargo cults done by Peter Lawrence (1921-1987) (Lawrence 1989 [1964]). The book Gods, Ghosts, and Men in Melanesia edited by Lawrence and Meggitt (1965) is the pioneering work of this era.

\section{CONCLUSION}

Anthropology as a discipline is particularly linked to Melanesia and especially to the territory of the current independent state of Papua New Guinea. It's possible to say that most of the important movements in anthropology were based or linked to the outputs of researches, which anthropologists conducted in Papua. We could sum up that Papua is a crucial cultural area where anthropology has been shaped as a holistic science of man and culture. Most considerable achievements and progress of the anthropology in Papua to the anthropology as such are as follow:

1. In Papua anthropologists laid the foundations of anthropology as a field science during Torres Expedition.

2. Development and verification of the genealogical method by Rivers during Torres Expedition.

3. Malinowski as one of the first anthropologists developed and applied a key method of participant observation, which he described in his classic (Malinowski 1922).

4. Fieldworks undertaken in Papua helped to shape different domains of anthropology: the economic anthropology, psy- chological anthropology, anthropology of gender, anthropology of body, anthropology of religion and political anthropology belong to the most important subfields. Brief overview of progress in anthropology on the base of fieldworks in Papua is tabled below (see table 3 ).

Anthropology as we know would not be the same without Papuans and Papuan cultures. There we can still meet a fascinating cultural and linguistic diversity as well as biodiversity. This part of the world magnetizes and attracts. It is easy to understand Malinowski's confession that his heart is in Melanesia (Malinowski 1932: XVII).

\section{REFERENCES}

Armstrong, Wallace E. (1928): Rossel Island: An Ethnological Study. Cambridge: Cambridge University Press.

Baal, Jan van (1971): Symbols for Communication: An Introduction to the Anthropological Study of Religion. Assen: Vangorcum.

Bateson, Gregory (1958 [1936]): Naven. Stanford: Stanford University Press.

Barth, Frederik (1975): Ritual and Knowledge among the Baktaman of New Guinea. New Haven: Yale University Press.

Barth, Frederik (1995 [1987]): Cosmologies in the Making. Cambridge: Cambridge University Press.

Barth, Frederik, ed. (2005): One Discipline, Four Ways. Chicago: University of Chicago Press.

Berndt, Ronald M. (1962): Excess and Restraint. Chicago: The University of Chicago Press.

Brown, Paula (1972): The Chimbu: A Study of Change in the New Guinea Highlands. Cambridge: Schenkman Publishing Company.

Brown, Paula (1979): Highland Peoples of New Guinea. Cambridge: Cambridge University Press.

Bulmer, Ralph N. H. (1960): Leadership and Social Structure among Kayaka People of the Western Highlands District of New Guinea. Ph.D. dissertation, Australian National University.

Codrington, R. H.: The Melanesians: Studies in their Anthropology and FolkLore. Oxford, The Clarendon Press 1891.

Collingridge, George (2007): The First Discovery of Australia and New Guinea. Lexington: BiblioBazaar.

Connolly, Bob - Anderson, Robin (1988): First Contact. New York: Viking Penguin Inc. 
Epstein, Arnold L. (1992): Matupit: Land, Politics, and Change among the Tolai of New Britain. Berkeley: University of California Press.

Epstein, Arnold L. (1992): In the Midst of Life: Affect and Ideation in the World of the Tolai. Berkeley: University of California Press.

Finsch, Otto (1888): Samoafahrten. Reisen in Kaiser Wilhelms-Land und Englisch-Neu-Guinea in den Jahren 1884 u. 1885 an Bord des Deutschen Dampfers „Samoa“. Leipzig: Ferdinand Hirt \& Sohn.

Finsch, Otto (1888-1893): Ethnologische Erfahrungen und Belegstücke aus der Südsee: Beschreibender Katalog einer Sammlung in k. k. naturhistorischen Hofmuseum in Wien (3 vol.). Wien: Alfred Holder.

Finsch, Otto (1996): Archipelago of the Contended People? Madang: Kristen Press.

Fortune, Reo F. (1932): Sorcerers of Dobu. London: George Routledge \& Sons, Ltd.

Fortune, Reo F. (1969 [1935]): Manus Religion. Lincoln: University of Nebraska Press.

Fortune, Reo F. (circa 1936): Men of Purari. Unpublished Manuscript. Fortune Archive. Wellington: Turnbull Library.

Fortune, Reo F. (1942): Arapesh. New York: American Ethnological Society.

Frazer, James G. (1890): The Golden Bough. London: Macmillan.

Gray, Geoffrey (1999): 'Being Honest to my Science': Reo Fortune and J. H. P. Murray, 1927-30. In: The Australian Journal of Anthropology, 10(1), 56-76.

Gray, Geoffrey (2008): E. W. P. Chinnery: A Self-Made Anthropologist. In: Lal, Brij V. - Luker, Vicki, eds., Telling Pacific Lives: Prisms of Process. Canberra: The Australian National University Press, 227-242.

Hays, Terence E., ed. (1992): Ethnographic Present: Pioneering Anthropologists in the Papua New Guinea Highlands. Berkeley: University of California Press.

Herdt, Gilbert (1981): Guardians of the Flutes: Idioms of Masculinity. New York: McGraw-Hill.

Herdt, Gilbert (1982): Editor's Preface. In: Herdt, Gilbert, ed., Rituals of Manhood: Male Initiation in Papua New Guinea. Berkeley: University of California Press, IX-XXVI.

Hogbin, Ian (1951): Transforming Scene: The Changing Culture of a New Guinea Village. London: Routledge \& Kegan Paul.

Hogbin, Ian (1996 [1970]): The Island of Menstruating Men. Prospect Heights: Waveland Press, Inc.

Jenness, Diamond - Ballantyne, Andrew (1920): The Northern d'Entrecasteaux. Oxford: Clarendon Press.

Jenness, Diamond - Ballantyne, Andrew (1928): Language, Mythology, and Songs of Bwaidoga, Goodenough Island, S. E. Papua. Polynesian Society, Memoirs 8.

Kardiner, Abram - Preble, Edward (1963): They Studied Man. New York: A Mentor Book.

Kuper, Adam (2005): Reinvention of Primitive Society: Transformations of a Myth. London: Routledge.

Landtman, Gunnar (1927): The Kiwai Papuans of British New Guinea. London: Macmillan.

Lawrence, David (2010): Gunnar Landtman in Papua: 1910 to 1912. Canberra: The Australian University Press.

Lawrence, Peter (1989 [1964]: Road Belong Cargo: A Study of the Cargo Movement in the Southern Madang District, New Guinea. Prospect Heights: Waveland Press.

Lawrence, Peter - Meggitt, Mervyn J., eds. (1965): Ghost, Gods, and Men in Melanesia. Melbourne: Melbourne University Press.

Leahy, Michael J. - Crain, Maurice (1937): The Land that Time Forgot. New York: Funk \& Wagnalls.

Leahy, Michael J. (1991): Explorations into Highland New Guinea. Tuscaloosa: The University of Alabama Press.

Malinowski, Bronisław. (1915): The Natives of Mailu: Preliminary Results of the Robert Mond Research Work in New Guinea. In: Transactions and Proceedings of the Royal Society of South Australia, 39, 494-706.

Malinowski, Bronisław K. (1922): Argonauts of the Western Pacific. London: George Routledge and Sons.

Malinowski, Bronisław K. (1926): Crime and Custom in Savage Society. London: Kegan Paul, Trench, Trubner \& Co, Ltd.

Malinowski, Bronisław K. (1927): Sex and Repression in Savage Society. London: Kegan Paul, Trench, Trubner \& Co, Ltd.

Malinowski, Bronisław K. (1929): The Sexual Life of Savages in Northwestern
Melanesia. London: George Routledge and Sons.

Malinowski, Bronisław K. (1932): Introduction. In: Fortune, Reo F. Sorcerers of Dobu. London: George Routledge \& Sons, Ltd.

Malinowski, Bronisław K. (1935): Coral Gardens and Their Magic. 2 Volumes. London: G. Allen and Unwin.

Malinowski, Bronisław K. (2002): A Scientific Theory of Culture and Other Essays. London: Routledge.

Mead, Margaret (1953 [1930]): Growing Up in New Guinea. New York: A Mentor Book.

Mead, Margaret (1935): Sex and Temperament in Three Primitive Societies. New York: William Morrow and Company, Inc.

Mead, Margaret (1946): Research on Primitive Children. In: Leonard Carmichael, ed., Manual of Child Psychology. New York: John Wiley and Sons, 735-780.

Mead, Margaret (1956): New Lives for Old. New York: William Morrow and Company, Inc.

Meggitt, Mervyn (1965): The Lineage System of the Mae-Enga of New Guinea. Edinburgh: Oliver \& Boyd.

Meggitt, Mervyn (1977): Blood is their Argument. Palo Alto: Mayfield.

Miklukho-Maklai, Nikolai N. (1982): Travels to New Guinea: Diaries, Letters, Documents. Moscow: Progress.

Moore, Clive (2003): New Guinea: Crossing Boundaries and History. Honolulu: University of Hawai'i Press.

Mückler, Hermann (2009): Einführung in die Ethnologie Ozeaniens. Wien: Facultas Verlags- und Buchhandels AG.

Powdermaker, Hortense (1971 [1930]): Life in Lesu: The Study of a Melanesian Society in New Ireland. New York: W. W. Norton \& Company, Ltd.

Rappaport, Roy A. (1984 [1968]): Pigs for the Ancestors. New Haven: Yale University Press.

Read, Kenneth E. (1965): The High Valley. New York: Charles Scribner's Sons.

Read, Kenneth E. (1965): Return to the High Valley. Berkeley: University of California Press.

Reay, Marie (1959): The Kuma: Freedom and Conformity in the New Guinea Highlands. Melbourne: Melbourne University Press.

Salisbury, Richard F. (1962): From Stone to Steel: Economic Consequences of Technological Change in New Guinea. Melbourne: Melbourne University Press

Seligman, Charles G. (1910): The Melanesians of British New Guinea. Cambridge University Press: Cambridge.

Strathern, Andrew (1971): The Rope of Moka. Cambridge: Cambridge University Press.

Strathern, Andrew (2000): Arrow Talk. Kent: Kent State University Press.

Strathern, Merilyn (1972): Women in Between: Female Role in a Male World. London: Seminar Press.

Strathern, Merilyn (1988): The Gender of the Gift. Berkeley: University of California Press.

Stocking, George (1982): Gatekeeper to the field: E. W. P. Chinnery and Ethnography of the New Guinea Mandate. History of Anthropology Newsletter, 9(2), 3-12.

Stocking, George W. (1992): The Ethnographer's Magic and Other Essays in the History of Anthropology. Madison: University of Wisconsin Press.

Thurnwald, Richard (1916): Bánaro Society. Social Organization and Kinship System of a Tribe of the Interior of New Guinea. Memoirs of the American Anthropological Association, 3(4), 251-412.

Thurnwald, Richard (1921): Die Gemeinde der Bánaro. Stuttgart: Enke.

Tuzin, Donald (1976): The Ilahita Arapesh: Dimensions of Unity. Berkeley: University of California Press.

Tuzin, Donald (1980): The Voice of the Tambaran. Berkeley: University of California Press.

Urry, James (1985): W. E. Armstrong and Social Anthropology at Cambridge 1922-1926. Man, 20(3), 412-433.

Watson, James B. (1983): Tairora Culture: Contingency and Pragmatism. Seattle: University of Washington Press.

Watson, Virginia D. (1965): Agarabi Female Roles and Family Structure. Ph.D. Dissertation, University of Chicago.

Whiting, John (1941): Becoming a Kwoma: Teaching and Training in a New Guinea Tribe. New Haven: Yale University Press.

Whittaker, July (1971): New Guinea: The Ethnohistory of First Culture Contacts. In: Inglis, Ken, ed., The History of Melanesia. Canberra: The Australian National University, 625-645. 
Williams, Francis E. (1928): Orokaiva Magic. Oxford: Oxford University Press.

Williams, Francis E. (1930): Orokaiva Society. London: Oxford University Press.

Williams, Francis E. (1936): Papuans of the Trans-Fly. Oxford: Oxford University Press.

Williams, Francis E. (1940): Drama of Orokolo. Oxford: Oxford University Press.

Williamson, Robert W. (1912): The Mafulu Mountain People of British New Guinea. MacMillan and Co.: London.

Wirz, Paul (1934): Die Gemeinde der Gogodara. Nova Guinea, 16(4), 371499.

\section{AUTHOR}

Soukup, Martin (26 March 1977, Praha), Czech culturologist and cultural anthropologist. Assistant professor of Department of Cul- tural Studies (Culturology) at The Faculty of Arts, Charles University in Prague. He also teaches at The Prague College of Psychosocial Studies. He focuses on history, methodology and theory of anthropology, bioculturology and philosophy of man and culture. Soukup is particularly interested in the cultural area of Melanesia. He undertook anthropological pre-research in Papua New Guinea in three local communities - Wannang (Madang Province), Kegeslugel (Chimbu Province) and Yawan (Morobe Province). Besides number of papers and articles, he is also the author of the textbook Essentials of Cultural Anthropology (2009, in Czech) and monograph Bioculturology: Evolution and Culture (2010, in Czech).

Contact: PhDr. Martin Soukup, Ph.D. The Department of Cultural Studies (Culturology), Faculty of Arts, Charles University in Prague, Celetná 20, 11000 Prague 1

e-mail: martin.soukup@ff.cuni.cz. 